\title{
Analisis Perbandingan Penggunaan Magnet Roycer dan 9power Terhadap Penghematan BBM Sepeda Motor Konvensional
}

\author{
Muhammad Ridha Fauzi, Ilma Alzikri \\ Program Studi Mesin Otomotif, Fakultas Teknik \\ Universitas Muhammadiyah Riau \\ e-mail: mridhafauzi@umri.ac.id
}

\begin{abstract}
Abstrak
Dengan bertambahnya kebutuhan bahan bakar timbullah pemikiran untuk membuat suatu alat yang dapat menghemat pemakaian bahan bakar baik berupa peralatan, cairan atau pun tablet. Salah satu cara penghematan bahan bakar adalah memberikan perlakuan terhadap bahan bakar sebelum memasuki ruang bakar atau sebelum mengalami proses pembakaran. Penggunaan magnet roycer, 9power dan mencoba menggabungkan magnet roycer dan 9power, dapat mengurangi pemakain bahan bakar yang digunakan pada sepeda motor konvesional.Pengujian dilakukan secara diam (engine stand) dengan waktu yang sudah ditentukan 10 menit pada motor suzuki $R 125 \mathrm{cc}$ dengan kecepatan rpm 1500, 2000, 2500 dan 3000 rpm. Dari hasil pengujian yang telah dilakukan, pemakaian magnet roycer dan 9power terjadi penghematan bahan bakar namun bila digabungkan magnet roycer dan 9power penghematan yang terjadi lebih besar lagi. Penghematan terjadi pada setiap kecepatan tetapi penghematan yang paling signifikan terjadi pada kecepatan $2500 \mathrm{rpm}$. Penggunaan magnet roycer dengan kecepatan $2500 \mathrm{rpm}$ menghasilkan penghematan sebesar $3,3 \mathrm{ml}$, penggunaan 9power dengan kecepatan yang sama menghasilkan penghematan sebesar $5 \mathrm{ml}$. Penggabungan magnet roycer dan 9power menghasilkan penghematan yang lebih besar lagi 21,7 ml, karna hasil pembakaran yang sempurna dan pengapian yang lebih baik.
\end{abstract}

Kata kunci : Konsumsi Bahan Bakar, Magnet Roycer, 9Power.

\begin{abstract}
With increasing fuel requirement arises the idea to create a device that could save fuel consumption in the form of equipment, liquid or tablet form. One way of saving fuel is to provide the treatment of the fuel before entering the combustion chamber or before experiencing the combustion process. The use of magnets roycer, and try to combine magnetic 9Power roycer and 9Power, can reduce the usage of fuel used on conventional motorcycles. Tests are done quietly (engine stand) with a specified time 10 minutes on a 125cc motorcycle suzuki $R$ speed rpm 1500, 2000, 2500 and 3000 rpm. From the testing that has been done, the use of magnets and 9Power roycer be saving fuel but combined magnet 9Power roycer and the savings are even greater. The savings occur at any speed but the most significant savings occur in speed $2500 \mathrm{rpm}$. The use of magnets roycer with a speed of $2500 \mathrm{rpm}$ resulting in savings of $3.3 \mathrm{ml}$, the use 9Power the same speed resulted in a savings of $5 \mathrm{ml}$. Merger magnet roycer and 9Power generate greater savings of $21.7 \mathrm{ml}$, because the result of perfect combustion and ignition better.
\end{abstract}

Keywords: Fuel Consumption, Magnet Roycer, 9Power.

\section{Pendahuluan}

Modifikasi dibidang otomotif mengalami perkembangan yang pesat dan beragam,seperti pada sepeda motor. Dewasa ini modifikasi pada kendaraan roda dua maupun pada roda empat banyak sekali dilakukan terutama pada penghematan bahan bakar.Mengingat pertumbuhan dunia otomotif dan pengguna kendaraan semakin besar peraturan pemerintah tentang umur kendaraan yang boleh beroperasi tidak dihiraukan oleh masyarakat sehingga jumlah kendaran semakin banyak. Dengan bertambahnya kebutuhan bahan bakar timbullah pemikiran untuk membuat suatu alat yang dapat menghemat pemakaian bahan bakar baik berupa peralatan, cairan ataupun tablet. Salah satu cara penghematan bahan bakar adalah memberikan perlakuan terhadap bahan bakar sebelum memasuki ruang bakar atau sebelum mengalami proses pembakaran..

Ada beberapa alat yang dapat menghemat bahan bakar yaitu Magnet Roycer dan 9Power. Magnet yang digunakan adalah magnet 
Neodymium, Magnet ini adalah Magnet terkuat yang tidak terbentuk secara alami, tetapi melalui proses pencampuran antara neodymium, besi dan boron. Manget ini akan dipasang di selang minyak yang mengarah ke karburator. 9Power adalah sebuah alat penguat arus yang berfungsi untuk menstabilkan arus listrik yang dihasilkan oleh koil sehingga proses pembakaran pada mesin menjadi sempurna. Pentingnya 9Power yaitu dapat mempersempit/memfokuskan arus listrik yang ada di dalam kabel busi sehingga menjadi 1 titik fokus ke busi karena api yang dihasilkan tidak menyebar melainkan menjadi 1 kesatuan yang tajam dan kuat.

Eko Santana dalam penelitiannya menggunakan sepeda motor merk Kawasaki KLX 150 yang menggunakan alat penghemat bahan bakar berupa Magnet Roycer yang dipasang di antara selang minyak dari tangki bahan bakar menuju karburator. Penelitian ini dilakukan dengan cara kendaraan dikemudikan pada kecepatan $20 \mathrm{~km} / \mathrm{jam}, 30 \mathrm{~km} / \mathrm{jam}, 40$ $\mathrm{km} / \mathrm{jam}, 50 \mathrm{~km} / \mathrm{jam}, 60 \mathrm{~km} / \mathrm{jam}, 70 \mathrm{~km} / \mathrm{jam}$, pada pengujian menunjukkan bahwa terjadi penghematan bahan bakar bila dibandingkan tanpa pemakaian Magnet Roycer [1].

Selanjutnya Teguh Agus Satria dalam penelitiannya menggunakan sepeda motor merk Yamaha Vega Z sebagai alat penghemat bahan bakar berupa 9Power yang dipasang pada kabel busi. Penelitian ini dilakukan dengan cara kendaraan dikemudikan Pada kecepatan 20 km/jam, 30 km/jam, 40 km/jam, 50 km/jam, 60 $\mathrm{km} / \mathrm{jam}, \quad 70 \mathrm{~km} / \mathrm{jam}$, pada pengujian menunjukkan bahwa terjadi penghematan bahan bakar bila dibandingkan tanpa pemakain 9Power [2].

Berbagai cara telah diupayakan dan dicoba untuk menghemat pemakaian bahan bakar, salah satu di antaranya adalah dengan memberikan medan magnet pada saluran bahan bakar menuju karburator. Dengan adanya medan magnet ini maka bahan bakar akan terinduksi oleh medan magnet tersebut dan akan mengalami restrukturasasi sehingga akan lebih mudah terbakar [3].

Penghemat bahan bakar magnetis adalah sistem penghemat bahan bakar yang berupa magnet alat ini dipasang di saluran bahan bakar sebelum masuk ke karburator. Bahan bakar, dalam hal ini bensin dialirkan lewat medan magnet akan menyebabkan perubahan orientasi kutub magnet dan konfigurasi molekul-molekul bahan bakar. Hal ini akan menyebabkan bahan bakar lebih mudah diubah menjadi partikelpartikel yang kecil yang memungkinkan terjadi pembakaran yang lebih sempurna di ruang bakar yang akan menigkatkan efisinsi motor bakar tersebut.

Tujuan penelitian yang dilakukan oleh peneliti ini adalah untuk mengetahui unjuk kerja dan penghematan bahan bakar mesin generator set merk General tipe ET 2500 L. Pengujian ini dilakukan dengan menggunakan alat voltmeter untuk mengukur tegangan, ampermeter untuk mengukur arus listrik, Tachometer untuk mengukur rpm. Selain itu alat ukur yang digunakan adalah gelas ukur yaitu alat yang digunakan untuk mengukur konsumsi bahan bakar.

Hasil penelitian terdahulu ini menunjukkan bahwa terdapat perbedaan konsumsi bahan bakar yang diperoleh pada generator set. Sistem penghemat bahan bakar mampu meningkatkan efisiensi generator set pada beban dan putaran rendah, yaitu pada beban $600 \mathrm{~W}$ dan putaran 1.600 rpm, dari 10,788 \% menjadi 13,54\%. Sedangkan pada putaran normal dan pembebanan penuh tidak terjadi kenaikan efisiensi yang signifikan.Pada kondisi putaran normal, yaitu $3.000 \mathrm{rpm}$, terjadi sedikit kenaikan efisiensi dan penurunan SFC pada pembebanan rendah dan menengah, sedangkan pada pembebanan penuh tidak terjadi perubahan yang siknifikan.Pada pembebanan rendah dan putaran rendah kemungkinan terjadi magnetisasi yang besar pada bahan bakar, sehingga berpengaruh terhadap efisiensi dan konsumsi bahan bakar.

Dari penelitian yang telah dipaparkan diatas, penulis tertarik untuk mencoba menggabungkan penggunakan kedua alat tersebut yaitu Magnet Roycer dengan 9power terhadap konsumsi bahan bakar sehingga diharapkan dapat lebih menghemat bahan bakar yang lebih singnifikan.

\subsection{Magnet}

Magnet adalah suatu objek yang mempunyai suatu medan magnet. Magnet merupakan benda yang dapat menarik benda-benda lain di sekitarnya seperti besi, baja, dan kobalt.Sebuah magnet terdiri atas magnet-magnet elementer yang tersusun secara teratur.Magnet mmepunyai bagian yang paling kuat daya tariknya yaitu bagian kutub magnet, terdiri dari kutub utara (U) dan kutub Selatan (S). Sifat-sifat kutub magnet adalah kutub-kutub sejenis jika didekatkan akan tolak menolak. Sedangkan kutub-kutub tidak sejenis jika didekatkan akan tarik menarik. Ruangan di sekitar magnet yang masih dipengaruhi adanya gaya magnet disebut medan magnet. Kuat medan magnet ditunjukkan oleh garis-garis magnet yang disebut fluks. 
Coulomb menemukan adanya medan gaya magnet yang dihasilkan diantara dua kutub berbeda. Kemudian teori berkembang lebih ke arah molekuler dimana pada tahun 1982 Webber.Dan dikembangkan oleh Ewing mengemukakan teori bahwa "molekul suatu zat benda, telah mengandung potensi magnet dengan masing-masing kutub N (utara) dan S (selatan)". Pada keadaan tidak termagnetisasi, molekul kecil magnet berada dalam bentuk tidak beraturan. Dan jika dipengaruhi medan magnet pada partikelnya, maka molekul tersebut mempunyai gaya magnet untuk bergerak dan menyesuaikan kutub magnet dengan induksi magnet yang diberikan. Akan tetapi dengan teori Atom dapat membantu menggambarkan fenomena tersebut. Disebutkan bahwa keseimbangan antara positif dan negatif elektron yang berputar mengelilingi inti atom mempengaruhi kuat atau tidaknya suatu zat dapat dipengaruhi medan magnet.

\subsection{Magnet Roycer}

Magnet Roycer adalah magnet penghemat bahan bakar yang berbahan Neodymium, yaitu magnet tetap yang paling kuat.Magnet Neodymium (juga dikenal sebagai $\mathrm{NdFeB}, \mathrm{NIB}$, atau magnet $\mathrm{Neo}$ ), merupakan sejenis magnet tanah jarang, terbuat dari campuran logam neodymium. Jenis magnet ini dikenal juga dengan sebutan "King Of Magnet". Magnet Roycer diproduksi dan dibuat oleh negara China, Taiwan dan Hongkong. Bahan pembuatnya adalah Nd2Fe14B Tetragonal Crystalline, sehingga magnet ini dinobatkan sebagai magnet terkuat yang memiliki kekuatan 10 kali lipat dari magnet biasa. Selain itu magnet jenis ini tahan terhadap suhu panas sampai dengan 135 Celcius, sementara suhu mesin di dalam kap mobil hanya berkisar 78-92 Celcius. Dengan daya tahan magnet yang kuat terhadap panas membuat Alat Penghemat BBM ini dapat digunakan lebih dari 7 tahun [4].

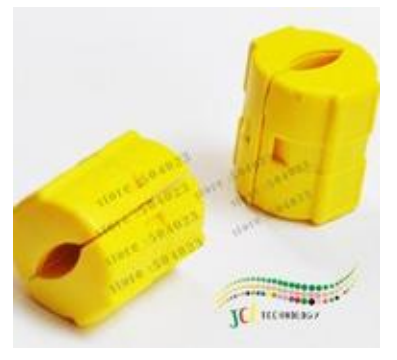

Gambar 1. Mangnet Roycerr [5]

\subsection{Cara Kerja Magnet Roycer}

Penghemat BBM Magnet merupakan suatu produk penghematan terhadap Hidro Karbon dengan teknologi Fuel Saver (Magnetism).
Melalui prinsip kerja merekayasa reaksi fisika terhadap perlakuan molekul kimia bahan bakar menjadi lebih reaktif, dengan menambah kecepatan putar elektron kimia bahan bakar melalui resonansi magnet permanen. Karbon dan Oksigen memiliki kutub magnet berseberangan dengan menggunakan Fuel Saver (Magnetism), maka Karbon dan Oksigen akan lebih mudah melebur menjadi satu menghasilkan pembakaran yang lebih baik dan lebih efisien. Hasil dari penggabungan bahan bakar dan udara, mesin akan bekerja lebih efisien, menghasilkan tenaga yang lebih besar, mengurangi konsumsi bahan bakar dan mengurangi pembuangan Hidro Karbon, Karbon Monoksida serta Nitrogen Oksida.

Unsur kimia pada bensin yaitu iso oktan (C8H18) dan n-pentana (C5H12). Medan magnet mempengaruhi kandungan karbon (C) dan hidrogen $(\mathrm{H})$ dalam bensin. Hingga bisa memaksimalkan proses pembakaran dan mengurangi kadar CO2. Unsur kimia pada bensin harus terionisasi dan disesuaikan kembali, ionisasi dan penataan kembali dicapai melalui penerapan medan magnet yang diciptakan oleh Magnet Roycer sehingga menghasilkan pembakaran yang lebih sempurna dalam ruang pembakaran. Hasilnya adalah output mesin yang lebih tinggi, penghematan bahan bakar dan pengurangan hidrokarbon, karbon monoksida dan nitrogen oksida. Juga membantu untuk melarutkan karbon dalam ruang pembakaran sehingga menjaga mesin dalam kondisi bersih.

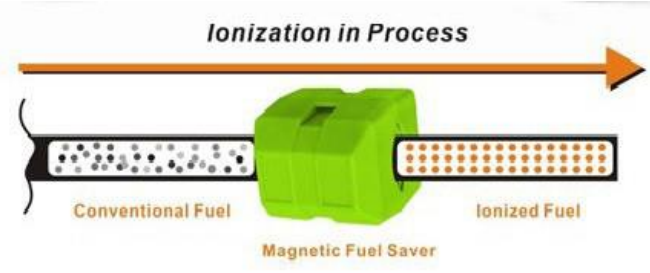

Gambar 2. Molekul Termagnetisasi [6]

\subsection{Power}

9Power adalah sebuah alat penguat arus yang berfungsi untuk menstabilkan arus listrik yang dihasilkan oleh koil. Sehingga, pembakaran mesinpun terjadi dengan sempurna. 9Power dapat mempersempit/memfokuskan arus listrik yang ada di dalam kabel busi sehingga menjadi 1 fokus tembak ke busi karena api yang dihasilkan tidak menyebar melainkan menjadi 1 kesatuan yang tajam dan kuat. 9Power membantu 98\% bensin terbakar sempurna. Selain itu, kegunaan tambahan dari penggunaan alat ini adalah kerja piston menjadi tidak berat dan berirama stabil sehingga akselerasi kendaraan bertambah. 


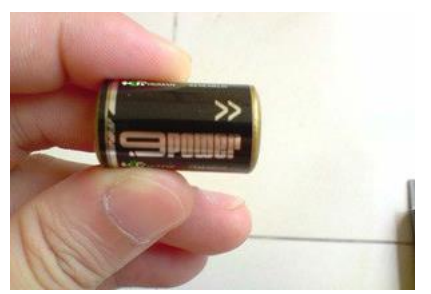

Gambar 3. 9Power [7]

\subsection{Cara Kerja 9Power}

Cara kerja 9Power adalah dengan menstabilkan arus listrik yang dihasilkan oleh koil (kita tidak tahu koil tersebut tegangannya naik turun atau stabil) untuk mendapatkan pembakaran yang sempurna arus tersebut harus stabil agar kerja pembakaran tidak tersendatsendat.

9Power menghilangkan arus yang liar dan mempersempit/memfokuskan arus listrik di dalam kabel busi sehingga menjadi 1 titik fokus ke busi dan api yang dihasilkan tidak menyebar melainkan menjadi 1 kesatuan yang tajam dan kuat, sehingga 9Power bisa dikatakan sebagai booster dan penguat arus listrik.

\subsection{Sistem Bahan Bakar}

Sistem Bahan Bakar Secara umum sistem bahan bakar yang ada pada sepeda motor, sistem bahan bakar berfungsi untuk menyediakan bahan bakar melakukan proses pencampuran bahan bakar dan udara dengan perbandingan yang tepat kemudian menyalurkan campuran tersebut ke dalam silinder dalam jumlah volume yang tepat sesuai kebutuhan putaran mesin. Cara untuk melakukan penyaluran bahan bakarnya dapat dibedakan menjadi dua, yaitu sistem penyaluran bahan bakar dengan sendirinya (karena berat gravitasi) dan sistem penyaluran bahan bakar dengan tekanan.

Sistem penyaluran bahan bakar dengan sendiri diterapkan pada sepeda motor yang masih menggunakan karburator (sistem bahan bakar konvensional). Pada system ini tidak diperlukan pompa bahan bakar dan penempatan tangki bahan bakar biasanya lebih tinggi dari karburator. Sedangkan sistem penyaluran bahan bakar dengan tekanan terdapat pada sepeda motor yang menggunakan sistem bahan bakar injeksi atau EFI (electronic fuel injection). Dalam sistem ini, peran karburator yang terdapat pada sistem bahan bakar konvensional diganti oleh injektor yang proses kerjanya di kontrol oleh unit pengontrol elektronik atau dikenal ECU (electronic control unit).

\subsection{Sistem Bahan Bakar Konvensional}

Sistem bahan bakar konvensional merupakan sistem bahan bakar yang mengunakan kaburator untuk melakukan proses pencampuran bensin dengan udara sebelum disalurkan ke ruang bakar. Sebagian besar sepeda motor saat ini masih menggunakan sistem ini. Komponen utama dari sistem bahan bakar terdiri dari: tangki dan karburator. Sepeda motor yang menggunakan sistem bahan bakar konvensional umumnya tidak dilengkapi dengan pompa bensin karena system penyalurannya tidak menggunakan tekanan tapi dengan penyaluran sendiri berdasarkan berat gravitasi [8].

\subsection{Fungsi Sistem Pengapian}

Sistem pengapian berfungsi menghasilkan percikan bunga api pada busi pada saat yang tepat untuk membakar campuran bahan bakar dan udara di dalam silinder. Seperti yang kita ketahui bahwa sistem pengapian konvensional menggunakan gerakan mekanik kontak platina untuk menghubung dan memutus arus primer, maka kontak platina mudah sekali aus dan memerlukan penyetelan/perbaikan dan penggantian setiap periode tertentu. Hal ini merupakan kelemahan mencolok dari sistem pengapian konvensional.

Dalam perkembangannya, ditemukan sistem pengapian elektronik sebagai penyempurna sistem pengapian.Salah satu sistem pengapian elektronik yang populer adalah sistem pengapian CDI (Capacitor Discharge Ignition). Sistem pengapian CDI merupakan sistem pengapian elektronik yang bekerja dengan memanfaatkan pengisian (charge) dan pengosongan (discharge) muatan kapasitor. Proses pengisian dan pengosongan muatan kapasitor dioperasikan oleh saklar elektronik seperti halnya kontak platina pada sistem pengapian konvensional [9].

\subsection{Konsumsi Bahan Bakar}

Konsumsi bahan bakar (FC) adalah parameter unjuk kerja mesin yang berhubungan langsung dengan nilai ekonomis sebuah mesin, karena dengan mengetahui hal ini dapat dihitung jumlah bahan bakar yang dibutuhkan untuk menghasilkan sejumlah daya dalam selang waktu tertentu.

Laju aliran bahan bakar adalah banyaknya bahan bakar yang terpakai pada waktu tertentu pada saat pengujian berlangsung dan dinyatakan dalam satuan (Ltr/jam). Untuk mengetahui berapa jumlah bahan bakar yang habis dari pengujian tersebut akan dimasukkan ke dalam rumus perhituangan konsumsi bahan bakar yang 
terpakai pada waktu tertentu. Adapun rumusnya sebagai berikut [9]:

$$
F C=\frac{V f \times 3600}{\mathrm{t} \times 1000}
$$

Dimana :

$$
\begin{array}{ll}
\mathrm{FC} & =\text { fuel consumption }(\mathrm{Ltr} / \mathrm{Jam}) \\
V f & =\text { volume } \operatorname{konsumsi}(\mathrm{ml}) \\
\mathrm{t} & =\text { waktu konsumsi }(\mathrm{det})
\end{array}
$$

\section{Methodologi}

Pada penelitian ini, penulis menggunakan metode Observasi, yaitu melakukan pengamatan dan pengujian langsung pada objek penelitian untuk memperoleh data-data pengujian, selanjutnya data yang diperoleh dianalisa untuk memperoleh kesimpulan antara kendaraan Standar, Magnet Roycer, 9Power dan menggabungkan kedua alat tersebut dalam keadaan kendaraan diam (engine stand). Proses penelitian dapat digambarkan dalam flowchart berikut.

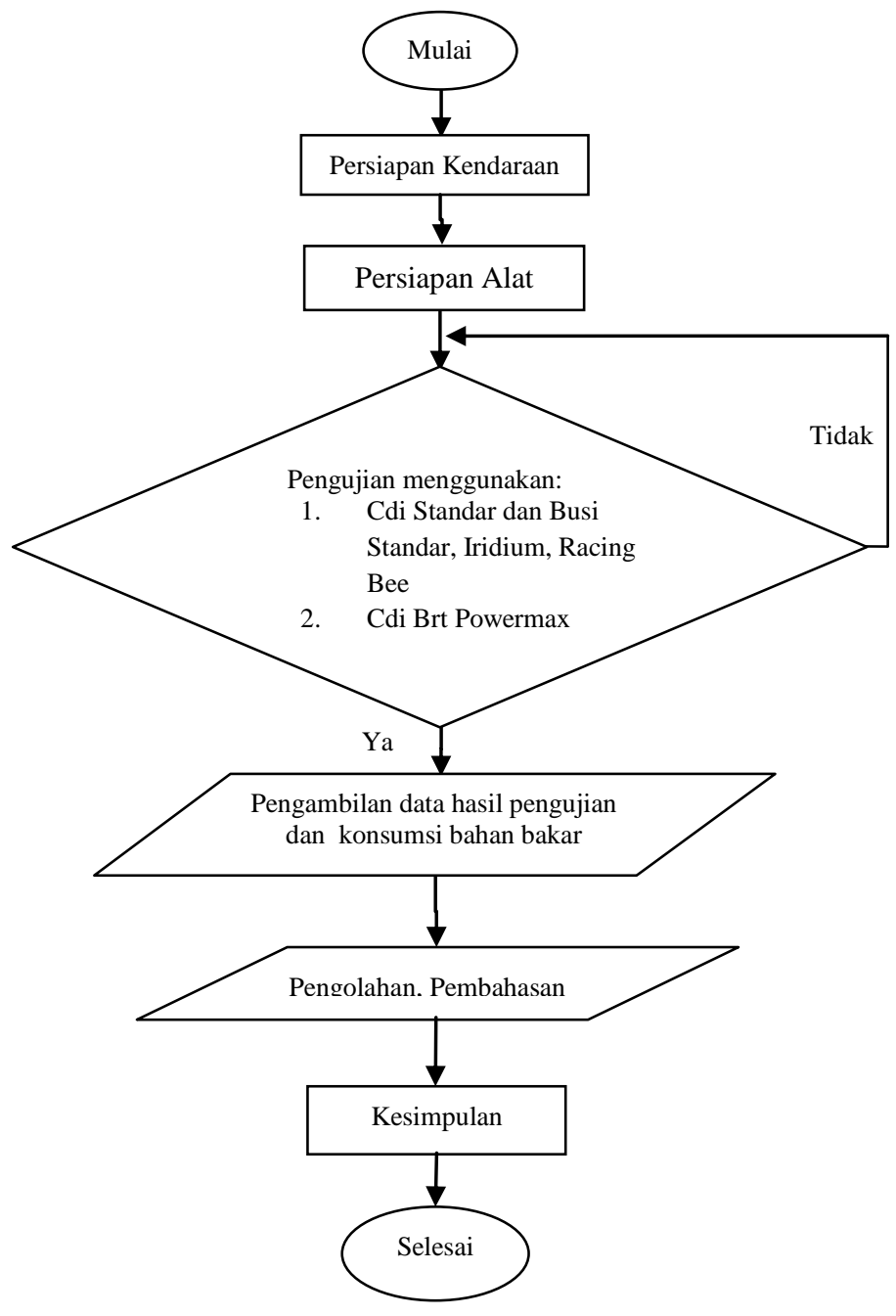

\section{Analisa dan Pembahasan}

\subsection{Hasil Pengujian}

Pengujian dilakukan pada saat kendaraan dalam keadaan diam (Stand) dan mesin dihidupkan dengan waktu yang sudah ditentukan yaitu selama 10 menit dengan volume awal bahan bakar sebesar $200 \mathrm{ml}$. Hasil pengujian antara sepeda motor standar dan sepeda motor menggunakan Magnet Roycer, 9Power dan penggabungan Magnet Roycer dan 9Power dapat dilihat padaTabel 1 sampai Tabel 3.

Tabel 1.

Pengujian Konsumsi Bahan Bakar pada Sepeda Motor Standar

\begin{tabular}{ccccc}
\hline & \multicolumn{3}{c}{ Konsumsi Bahan Bakar } & $\begin{array}{c}\text { Rata-rata } \\
\text { Konsumsi } \\
\text { Putaran }\end{array}$ \\
\cline { 2 - 4 } & $\begin{array}{c}\text { Pengujian } \\
1(\mathrm{ml})\end{array}$ & $\begin{array}{c}\text { Pengujian } \\
2(\mathrm{ml})\end{array}$ & $\begin{array}{c}\text { Pengujian } \\
3(\mathrm{ml})\end{array}$ & $\begin{array}{c}\text { Bahan Bakar } \\
(\mathrm{ml})\end{array}$ \\
\hline 1500 & 140 & 140 & 140 & 140 \\
2000 & 120 & 115 & 120 & 118 \\
2500 & 130 & 125 & 130 & 128 \\
3000 & 150 & 145 & 150 & 148 \\
\hline
\end{tabular}

Tabel 2.

Pengujian Konsumsi Bahan Bakar pada Sepeda Motor Menggunakan Magnet Roycer

\begin{tabular}{ccccc}
\hline & \multicolumn{3}{c}{ Konsumsi Bahan Bakar } & $\begin{array}{c}\text { Rata-rata } \\
\text { Putaran } \\
(\mathrm{rpm})\end{array}$ \\
\cline { 2 - 4 } & $\begin{array}{c}\text { Pengujian } \\
1(\mathrm{ml})\end{array}$ & $\begin{array}{c}\text { Pengujian } \\
2(\mathrm{ml})\end{array}$ & $\begin{array}{c}\text { Pengujian } \\
3(\mathrm{ml})\end{array}$ & $\begin{array}{c}\text { Bahan Bakar } \\
(\mathrm{ml})\end{array}$ \\
\hline 1500 & 135 & 130 & 130 & 131,7 \\
2000 & 115 & 115 & 120 & 116,7 \\
2500 & 125 & 125 & 125 & 125 \\
3000 & 140 & 140 & 145 & 141,7 \\
\hline
\end{tabular}

Tabel 3.

Pengujian Konsumsi Bahan Bakar pada Sepeda Motor Menggunakan Magnet 9Power

\begin{tabular}{ccccc}
\hline & \multicolumn{3}{c}{ Konsumsi Bahan Bakar } & $\begin{array}{c}\text { Rata-rata } \\
\text { Konsumsi } \\
\text { Putaran } \\
\text { (rpm) }\end{array}$ \\
\cline { 2 - 4 } & $\begin{array}{c}\text { Pengujian } \\
1(\mathrm{ml})\end{array}$ & $\begin{array}{c}\text { Pengujian } \\
2(\mathrm{ml})\end{array}$ & $\begin{array}{c}\text { Pengujian } \\
3(\mathrm{ml})\end{array}$ & $\begin{array}{c}\text { Bakar }(\mathrm{ml}) \\
\text { Bakn }\end{array}$ \\
\hline 1500 & 135 & 130 & 125 & 130 \\
2000 & 115 & 115 & 110 & 113 \\
2500 & 120 & 130 & 120 & 123 \\
3000 & 135 & 140 & 135 & 136,7 \\
\hline
\end{tabular}


Tabel 4.

Pengujian Konsumsi Bahan Bakar pada Sepeda Motor Menggunakan Magnet Roycer dan 9Power

\begin{tabular}{|c|c|c|c|c|}
\hline \multirow{2}{*}{$\begin{array}{c}\text { Putaran } \\
\text { (rpm) }\end{array}$} & \multicolumn{3}{|c|}{ Konsumsi Bahan Bakar } & \multirow{2}{*}{$\begin{array}{c}\text { Rata-rata } \\
\text { Konsumsi } \\
\text { Bahan Bakar } \\
\text { (ml) }\end{array}$} \\
\hline & $\begin{array}{l}\text { Pengujian } \\
1 \text { (ml) }\end{array}$ & $\begin{array}{c}\text { Pengujian } \\
2(\mathrm{ml})\end{array}$ & $\begin{array}{l}\text { Pengujian } \\
3(\mathrm{ml})\end{array}$ & \\
\hline 1500 & 125 & 120 & 120 & 121,7 \\
\hline 2000 & 105 & 100 & 100 & 101,7 \\
\hline 2500 & 110 & 105 & 105 & 106,7 \\
\hline 3000 & 120 & 115 & 115 & 116,7 \\
\hline
\end{tabular}

Jika data hasil pengujian dibuat ke dalam bentuk grafik, maka perbandingan konsumsi bahan bakar pada kendaraan Standar, menggunakan Magnet Roycer, 9Power dan penggabungan Magnet Roycer dan 9Power adalah sebagai berikut:

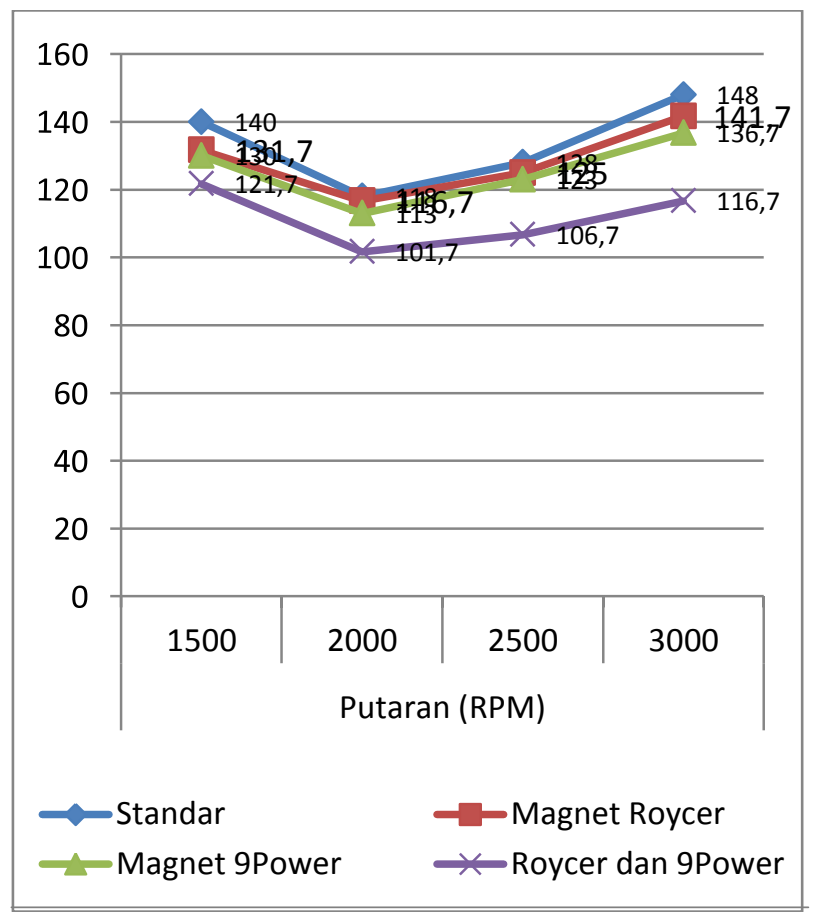

Gambar 4. Konsumsi Bahan Bakar Kendaraan Standar, menggunakan Magnet Roycer dan 9Power dan penggabungan Magnet Roycer dan 9Power

Dari Gambar 4 dapat dianalisa hasil pengujian di atas:

a. Pada kecepatan $1500 \mathrm{rpm}$, konsumsi bahan bakar kendaraan standar sebesar $140 \mathrm{ml}$, konsumsi bahan bakar kendaraan yang menggunakan Magnet Roycer sebesar 131,6 $\mathrm{ml}$, sedangkan konsumsi bahan bakar kendaraan yang menggunakan 9Power sebesar $130 \mathrm{ml}$, dan kendaraan yang menggabungkan Magnet Roycer dan 9Power mengkonsumsi bahan bakar sebesar 121,6 ml. Maka penghematan bahan bakar antara kendaraan standar dengan yang menggunakan Magnet Roycer sebesar 8,4 ml, dengan yang menggunakan 9Power sebesar $10 \mathrm{ml}$, penghematan bahan bakar kendaraan standar dengan penggabungan Magnet Roycer dan 9Power sebesar 18,4 ml, sedangkan penghematan bahan bakar antara yang menggunakan Magnet Roycer dengan penggabungan Magnet Roycer dan 9Power sebesar $10 \mathrm{ml}$ dan antara yang menggunakan 9Power dengan penggabungan Magnet Roycer dan 9Power sebesar 8,4 ml.

b. Pada kecepatan 2000 rpm, konsumsi bahan bakar kendaraan standar sebesar 118,3 ml, konsumsi bahan bakar kendaraan yang menggunakan Magnet Roycer sebesar 116,6 $\mathrm{ml}$, sedangkan konsumsi bahan bakar kendaraan yang menggunakan 9Power sebesar 113,3 ml, dan kendaraan yang menggabungkan Magnet Roycer dan 9Power mengkonsumsi bahan bakar sebesar 101,6 ml. Maka penghematan bahan bakar antara kendaraan standar dengan yang menggunakan Magnet Roycer sebesar 1,7 ml, dengan yang menggunakan 9Power sebesar 5 ml, penghematan bahan bakar kendaraan standar dengan penggabungan Magnet Roycer dan 9Power sebesar 16,7 ml, sedangkan penghematan bahan bakar antara yang menggunakan Magnet Roycer dengan penggabungan Magnet Roycer dan 9Power sebesar $15 \mathrm{ml}$ dan antara yang menggunakan 9Power dengan penggabungan Magnet Roycer dan 9Power sebesar 11,7 ml.

c. Pada kecepatan $2500 \mathrm{rpm}$, konsumsi bahan bakar kendaraan standar sebesar 128,3 ml, konsumsi bahan bakar kendaraan yang menggunakan Magnet Roycer sebesar 125 ml, sedangkan konsumsi bahan bakar kendaraan yang menggunakan 9Power sebesar 123,3 ml, dan kendaraan yang menggabungkan Magnet Roycer dan 9Power mengkonsumsi bahan bakar sebesar 106,6 ml. Maka penghematan bahan bakar antara kendaraan standar dengan yang menggunakan Magnet Roycer sebesar 3,3 ml, dengan yang menggunakan 9Power sebesar 5 $\mathrm{ml}$, penghematan bahan bakar kendaraan standar dengan penggabungan Magnet Roycer dan 9Power sebesar 21,7 ml, sedangkan penghematan bahan bakar antara 
yang menggunakan Magnet Roycer dengan penggabungan Magnet Roycer dan 9Power sebesar 18,4 $\mathrm{ml}$ dan antara yang menggunakan 9Power dengan penggabungan Magnet Roycer dan 9Power sebesar 16,7 ml.

d. Pada kecepatan $3000 \mathrm{rpm}$, konsumsi bahan bakar kendaraan standar sebesar 148,3 ml, konsumsi bahan bakar kendaraan yang menggunakan Magnet Roycer sebesar 141,6 $\mathrm{ml}$, sedangkan konsumsi bahan bakar kendaraan yang menggunakan 9Power sebesar 136,6 ml, dan kendaraan yang menggabungkan Magnet Roycer dan 9Power mengkonsumsi bahan bakar sebesar 116,6 ml. Maka penghematan bahan bakar antara kendaraan standar dengan yang menggunakan Magnet Roycer sebesar 6,7 ml, dengan yang menggunakan 9Power sebesar 11,7 ml, penghematan bahan bakar kendaraan standar dengan penggabungan Magnet Roycer dan 9Power sebesar 31,7 ml, sedangkan penghematan bahan bakar antara yang menggunakan Magnet Roycer dengan penggabungan Magnet Roycer dan 9Power sebesar $25 \mathrm{ml}$ dan antara yang menggunakan 9Power dengan penggabungan Magnet Roycer dan 9Power sebesar $20 \mathrm{ml}$.

\subsection{Perhitungan Fuel Consumption}

Fuel Consumption adalah banyaknya bahan bakar yang terpakai pada waktu tertentu pada saat pengujian berlangsung dan dinyatakan dalam satuan (Ltr/jam). Pada pengujian ini penulis menggunakan volume konsumsi rata-rata bahan bakar dan waktu yang sudah di tetapkan dari pengujian yang telah dilakukan sebelumnya (10 menit). Untuk mengetahui berapa jumlah bahan bakar yang habis terbakar pada setiap kecepatan dalam pengujian, maka data pengujian akan dimasukkan ke dalam persamaan 1. Berdasarkan data waktu yang sudah ditetapkan dan konsumsi rata-rata bahan bakar pada Tabel 1 sampai Tabel 4 maka Fuel Consumption untuk setiap pengujian adalah seperti pada Tabel 5 sampai dengan Tabel 8.

Tabel 5. Fuel Consumption pada Kendaraan Standar

\begin{tabular}{cccc}
\hline No & $\begin{array}{c}\text { Putaran } \\
\text { (rpm) }\end{array}$ & $\begin{array}{c}\text { Volume } \\
\text { konsumsi } \\
\text { Rata-rata } \\
(\text { Vf) }\end{array}$ & $\begin{array}{c}\text { FC } \\
\text { (Ltr/Jam) }\end{array}$ \\
\hline 1 & 1500 & 140 & 0,84 \\
2 & 2000 & 118,3 & 0,70 \\
3 & 2500 & 128,3 & 0,76 \\
4 & 3000 & 148,3 & 0,88 \\
\hline
\end{tabular}

Tabel 6. Fuel Consumption pada Kendaraan Menggunakan Magnet Roycer

\begin{tabular}{cccc}
\hline No & $\begin{array}{c}\text { Putaran } \\
(\mathrm{rpm})\end{array}$ & $\begin{array}{c}\text { Volume } \\
\text { konsumsi } \\
\text { Rata-rata } \\
(\mathrm{Vf})\end{array}$ & $\begin{array}{c}\text { FC } \\
(\text { Ltr/Jam) }\end{array}$ \\
\hline 1 & 1500 & 131,6 & 0,79 \\
2 & 2000 & 116,6 & 0,69 \\
3 & 2500 & 125 & 0,75 \\
4 & 3000 & 141,6 & 0,85 \\
\hline
\end{tabular}

Tabel 7. Fuel Consumption pada Kendaraan Menggunakan Magnet 9Power

\begin{tabular}{cccc}
\hline No & $\begin{array}{c}\text { Putaran } \\
(\mathrm{rpm})\end{array}$ & $\begin{array}{c}\text { Volume } \\
\text { konsumsi } \\
\text { Rata-rata } \\
(\mathrm{Vf})\end{array}$ & $\begin{array}{c}\text { FC } \\
\text { (Ltr/Jam) }\end{array}$ \\
\hline 1 & 1500 & 130 & 0,78 \\
2 & 2000 & 113,3 & 0,67 \\
3 & 2500 & 123,3 & 0,73 \\
4 & 3000 & 136,6 & 0,81 \\
\hline
\end{tabular}

Tabel 8. Fuel Consumption pada Kendaraan Menggunakan Magnet Roycer dan 9Power

\begin{tabular}{cccc}
\hline No & $\begin{array}{c}\text { Putaran } \\
(\mathrm{rpm})\end{array}$ & $\begin{array}{c}\text { Volume } \\
\text { konsumsi } \\
\text { Rata-rata } \\
(\text { Vf) }\end{array}$ & $\begin{array}{c}\text { FC } \\
\text { (Ltr/Jam) }\end{array}$ \\
\hline 1 & 1500 & 121,6 & 0,72 \\
2 & 2000 & 101,6 & 0,60 \\
3 & 2500 & 106,6 & 0,63 \\
4 & 3000 & 116,6 & 0,69 \\
\hline
\end{tabular}

Data dia atas jika ditampilkan dalam bentuk tabelmenjadi:

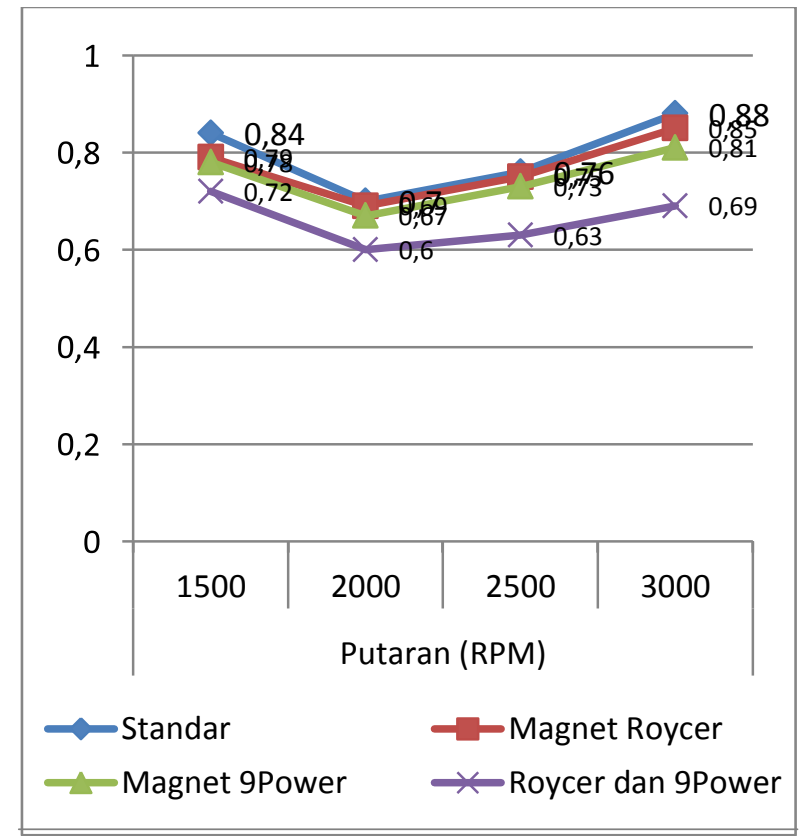


Gambar 5. Konsumsi Bahan Bakar berdasarkan Fuel Consumption Pada Kendaraan Standar, Magnet Roycer dan 9Power dan penggabungan Magnet Roycer dan 9Power.

Dari gambar 5 dapat dianalisa hasil pengujian di atas:

a. Pada kecepatan 1500 rpm, konsumsi bahan bakar kendaraan standar sebesar $0,84 \mathrm{ml}$, konsumsi bahan bakar kendaraan yang menggunakan Magnet Roycer sebesar 0,79 $\mathrm{ml}$, sedangkan konsumsi bahan bakar kendaraan yang menggunakan 9Power sebesar 0,78 ml, dan kendaraan yang menggabungkan Magnet Roycer dan 9Power mengkonsumsi bahan bakar sebesar $0,72 \mathrm{ml}$. Maka penghematan bahan bakar antara kendaraan standar dengan yang menggunakan Magnet Roycer sebesar 0,05 $\mathrm{ml}$, dengan yang menggunakan 9Power sebesar 0,06 $\mathrm{ml}$, penghematan bahan bakar kendaraan standar dengan penggabungan Magnet Roycer dan 9Power sebesar 0,12 ml, sedangkan penghematan bahan bakar antara yang menggunakan Magnet Roycer dengan penggabungan Magnet Roycer dan 9Power sebesar 0,07 $\mathrm{ml}$ dan antara yang menggunakan 9Power dengan penggabungan Magnet Roycer dan 9Power sebesar 0,06 ml.

b. Pada kecepatan 2000 rpm, konsumsi bahan bakar kendaraan standar sebesar $0,70 \mathrm{ml}$, konsumsi bahan bakar kendaraan yang menggunakan Magnet Roycer sebesar 0,69 $\mathrm{ml}$, sedangkan konsumsi bahan bakar kendaraan yang menggunakan 9Power sebesar 0,67 ml, dan kendaraan yang menggabungkan Magnet Roycer dan 9Power mengkonsumsi bahan bakar sebesar 0,60 ml. Maka penghematan bahan bakar antara kendaraan standar dengan yang menggunakan Magnet Roycer sebesar 0,01 $\mathrm{ml}$, dengan yang menggunakan 9Power sebesar 0,03 $\mathrm{ml}$, penghematan bahan bakar kendaraan standar dengan penggabungan Magnet Roycer dan 9Power sebesar 0,1 ml, sedangkan penghematan bahan bakar antara yang menggunakan Magnet Roycer dengan penggabungan Magnet Roycer dan 9Power sebesar 0,09 $\mathrm{ml}$ dan antara yang menggunakan 9Power dengan penggabungan Magnet Roycer dan 9Power sebesar 0,07 ml.

c. Pada kecepatan $2500 \mathrm{rpm}$, konsumsi bahan bakar kendaraan standar sebesar $0,76 \mathrm{ml}$, konsumsi bahan bakar kendaraan yang menggunakan Magnet Roycer sebesar 0,75 $\mathrm{ml}$, sedangkan konsumsi bahan bakar kendaraan yang menggunakan 9Power sebesar $0,73 \mathrm{ml}$, dan kendaraan yang menggabungkan Magnet Roycer dan 9Power mengkonsumsi bahan bakar sebesar 0,63 ml. Maka penghematan bahan bakar antara kendaraan standar dengan yang menggunakan Magnet Roycer sebesar 0,01 $\mathrm{ml}$, dengan yang menggunakan 9Power sebesar 0,03 $\mathrm{ml}$, penghematan bahan bakar kendaraan standar dengan penggabungan Magnet Roycer dan 9Power sebesar 0,13 ml, sedangkan penghematan bahan bakar antara yang menggunakan Magnet Roycer dengan penggabungan Magnet Roycer dan 9Power sebesar 0,12 $\mathrm{ml}$ dan antara yang menggunakan 9Power dengan penggabungan Magnet Roycer dan 9Power sebesar 0,1 ml.

d. Pada kecepatan 3000 rpm, konsumsi bahan bakar kendaraan standar sebesar $0,88 \mathrm{ml}$, konsumsi bahan bakar kendaraan yang menggunakan Magnet Roycer sebesar 0,85 ml, sedangkan konsumsi bahan bakar kendaraan yang menggunakan 9Power sebesar 0,81 $\mathrm{ml}$, dan kendaraan yang menggabungkan Magnet Roycer dan 9Power mengkonsumsi bahan bakar sebesar 0,69 $\mathrm{ml}$. Maka penghematan bahan bakar antara kendaraan standar dengan yang menggunakan Magnet Roycer sebesar 0,03 $\mathrm{ml}$, dengan yang menggunakan 9Power sebesar 0,07 $\mathrm{ml}$, penghematan bahan bakar kendaraan standar dengan penggabungan Magnet Roycer dan 9Power sebesar 0,19 ml, sedangkan penghematan bahan bakar antara yang menggunakan Magnet Roycer dengan penggabungan Magnet Roycer dan 9Power sebesar 0,16 $\mathrm{ml}$ dan antara yang menggunakan 9Power dengan penggabungan Magnet Roycer dan 9Power sebesar 0,12 ml.

\section{Ssimpulan}

Dari hasil pengujian konsumsi bahan bakar pada kendaraan Standar, Magnet Roycer, 9Power dan pengabungan Magnet Roycer dan 9Power dengan kecepatan rpm yang berbeda dan waktu yang sudah ditetapkan dapat dibuat kesimpulan yaitu:

1. Perbandingan konsumsi bahan bakar antara kendaraan standar, Magnet Roycer, 9Power atau penggabungan Magnet Roycer. Misalnya pegujian dengan kecepatan $2500 \mathrm{rpm}$ dengan waktu 10 menit, pada kendaraan standar menghabiskan 128,3 ml, pada kendaraan menggunakan Magnet Roycer menghabiskan $125 \mathrm{ml}$, pada kendaraan menggunakan 9Power menghabiskan 123,3 $\mathrm{ml}$, pada 
kendaraan penggabungan Magnet Roycer dan 9Power menghabiskan 106,6 ml.

2. Pengaruh penggunaan Magnet Roycer dan 9Power bila digabungkan terjadi penghematan bahan bakar disetiap kecepatan namun pada kecepatan 2000 dan 2500 rpm terjadi penghematan yang cukup signifikan. Misalnya pada kendaraan di kecepatan 1500 rpm menghabiskan bahan bakar $140 \mathrm{ml}$ dan kecepatan $2000 \mathrm{rpm}$ menghabiskan bahan bakar 118,3 ml. Sementara pada kendaraan yang menggunakan penggabungan Magnet Roycer dan 9Power di kecepatan 1500 rpm menghabiskan 121,6 ml, maka terjadi penghematan sebanyak 18,4 ml. dan kecepatan 2000 rpm menghabiskan 101,6 ml, maka terjadi penghematan sebanyak $16,7 \mathrm{ml}$. Pada kecepatan $2500 \mathrm{rpm}$ menghabiskan bahan bakar 128,3 ml dan pada kecepatan 3000 rpm menghabiskan bahan bakar 148,3 ml. Sementara pada kendaraan yang menggunakan penggabungan Magnet Roycer dan 9Power di kecepatan $2500 \mathrm{rpm}$ menghabiskan 106,6 $\mathrm{ml}$, maka terjadi penghematan sebanyak 21,7 $\mathrm{ml}$ dan di kecepatan 3000 rpm menghabiskan 116,6 ml, maka terjadi penghematan sebanyak $31,7 \mathrm{ml}$.

3. Pada pegujian yang sudah dilakukan menghasilkan Jumlah penghematan bahan bakar pada Magnet Roycer dan 9Power jika digabungkan: Pada kecepatan 1500 rpm menghabiskan 121,6 $\mathrm{ml}$ bahan bakar dalam waktu 10 menit, menghemat bahan bakar sebanyak 18,4 ml. Pada kecepatan 2000 rpm menghabiskan 101,6 ml bahan bakar dalam waktu 10 menit, menghemat bahan bakar sebanyak 16,7 ml. Pada kecepatan 2500 rpm menghabiskan 106,6 ml bahan bakar dalam waktu 10 menit, menghemat bahan bakar sebanyak 21,7 ml. Pada kecepatan 3000 rpm menghabiskan 116,6 ml bahan bakar dalam waktu 10 menit, menghemat bahan bakar sebanyak $31,7 \mathrm{ml}$.

\section{Daftar Pustaka}

[1] Eko Santana, 2015, Perbandingan Konsumsi Bahan Bakar Antara Kendaraan Standar Dengan Kendaraan Menggunakan Magnet Roycer Sebagai Alternatif Penghemat BBM Fakultas Teknik UMRI..

[2] Teguh agus satria, 2015, Pengaruh Penggunaan 9power Pada Kabel Busi Terhadap Pengapian Dan Penghematan BBM Sepeda Motor Fakultas Teknik UMRI.
[3] Muhammad abdul kadir, 2013, Pengaruh Pemasangan Alat Penghemat BahanBakar Magnetis Terhadap Efisiensi Dan KonsumsiBahan Bakar Spesifik Motor Bensin

[4] Sungkono, Djoko, 2010.

[5] www.dhgate.com/reviews/magneticpowered-car-reviews.html

[6] http://penghematbbm.org/cara-kerjapenghemat-bbm-berbahanmagnet.

[7] http://penghematbbm.org/blog/pasang9power-vixion

[8] Jama, Jalius. Wagino, 2008, Teknik Sepeda Motor Jilid 2 Untuk SMK, Penerbit Direktorat Pembinaan Sekolah Menengah Kejuruan.

[9] Rossy Febriyant. Otomotif Untuk Pemula. CV Gunung Mas. 2000. 